\title{
New data on some matorralized soils in the western Algerian region
}

\author{
Fatima Zohra Meftah, Noury Benabadji \& Abdessamad Merzouk
}

University Aboubekr Belkaid, Laboratoire d'Ecologie et Gestion des Ecosystèmes Naturels, Université de Tlemcen BP 119, 13000 Tlemcen, Algeria; e-mail: m_fz13@yahoo.fr, as_merzouk@yahoo.fr

\begin{abstract}
This paper continues the work carried out to determine the influence of soil physico-chemical factors on the spatial distribution of matorrals in the plain from Remchi to Béni-Saf located in the western region of Algeria and on the relationships that soil can have on the diversity of matorrals. On the bioclimatic level, the region is characterized by semi-aridity accentuating the phenomena of thérophysation. Soil analysis was carried out using known methods (Stokes Particle Size Method, Electrometric Method for $\mathrm{pH}, 1 / 5$ Extract Method for Electrical Conductivity, Bernard Calcium Method for Ca CO3, Anne Method for Organic Carbon). The results confirm the following characteristics: sandy-muddy "Remchi", sandy "Rachgoun 1 and Rechgoun 2", not far from Béni-Saf. The low clay content (Remchi: Profile 1: Horizon 1 clays 9\%, Profile 2: Horizon 1: Clays 12\%, Profile 3: Horizon 1: Clays 16\%, Rechgoun Profile 1: Horizon 1: Clays 5\%, Profile 3: Horizon 1: 5\% clays and Horizon 2: 6\% clays) leads to poor structural stability and degradation of the soil surface due to visible erosion especially on steep slopes.
\end{abstract}

KEY WORDS Soil vulnerability; anthropization; Matorral; Mediterranean region; Western Algeria.

Received 07.12.2020; accepted 06.03.2020; published online 23.04.2021

\section{INTRODUCTION}

Soil is the natural surface formation, of varying thickness, resulting from the transformation of the rock under the influence of various chemical, biological, and physical processes.

It contains a mineral fraction and an organic fraction (Guinochet, 1973), regulates the distribution of vegetation (Ozenda, 1997) and plays a protective role in atmospheric precipitation (Benabadji et al., 1996). Its content of water (Meziane, 2010) and nutritive elements are crucial for all biological phenomena that take place in it (Duchaufour, 1977).

The soil is a resource for human development, but this environment can be damaged by human ac- tivity (Collier et al., 1957; Baize, 1988; Laperche \& Moussman, 2004; Merzouk et al., 2009; Lahouel et al., 2014) failing to carry out its important ecological functions (Robert, 1992; Benabdelmoumene, 2018). The vulnerability of a soil depends very much on its vegetation cover, its exposure to the sun and other atmospheric agents such as winds and rains (Roose, 1991).

In the Mediterranean region, the Matorral has very diversified soils due to numerous natural factors (climate, vegetation, physiography, geology and lithology) which condition its formation and distribution.

Often the definition of soil is difficult because the terminology used to describe the limestone component is not clear. 
Following Ruellan (1972), it is possible use the term "calcareous soil" to include the "laminated soils" and "compact slab soils" (slab and crust). Duchaufour (1977) also clarified that all the socalled steppe soils belong to the class of isohumid soils (brown steppe soils). In any case, the distinction between the two types of soils is easily observed, despite a large number of transition profiles.

It is possible, in our study, to see how a certain number of soils are structured and we will try to highlight a differentiation between edaphic parameters and between the profiles of the different horizons, at the littoral level (Aubert \& Chalabi, 1981), on a matorral vegetation examined in a fairly steep territory.

We have already provided some preliminary data (Meftah et al., 2019) and, in this work, we will provide new data some matorralized soils in the western Algerian region.

\section{MATERIAL AND METHODS}

\section{Study area}

The soils of the Matorrals of the study area (western Algeria) occupy varied topographical location and have different properties.

1. "Remchi" Station. The Remchi station is close to the national road No. 22 Remchi - BeniSaf. It rises to an altitude of $60 \mathrm{~m}$ and presents the

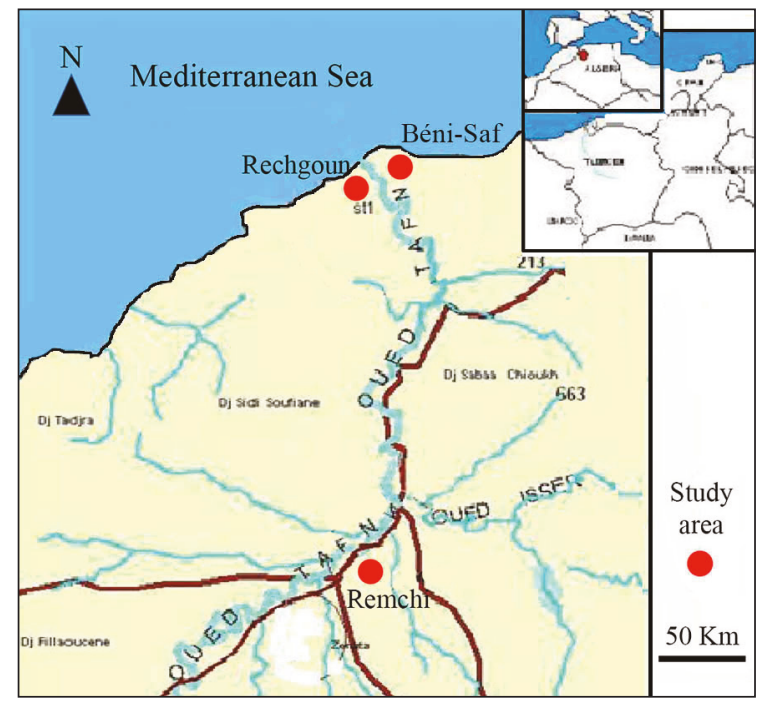

Figure 1. Study area. following Lambert coordinates: $1^{\circ} 42^{\prime}$ West longitude, $35^{\circ} 19^{\prime}$ North latitude.

The station is on a slope of $30 \%$ and is limited by plots of cereal crops. The vegetation cover rate is 60 to $70 \%$ represented by Chamephytes as Drimia maritima (L.) Stearn, Chamaerops humilis L. (doum) and some annual species.

2. "Rachgoun 1" Station. The Rachgoun 1 station is approximately $1.2 \mathrm{~km}$ from the crossroads of the national road 22, on the path leading to BéniSaf. It rises to an altitude of $35 \mathrm{~m}$ and has the following Lambert coordinates: $1^{\circ} 41^{\prime}$ West longitude, $35^{\circ} 22^{\prime}$ North latitude.

The rate of vegetation cover varies from 60 to $70 \%$ on a slope of 30 to $40 \%$ with a vegetation composed largely of: Olea europea L., Chamaerops humilis, Drimia maritima and Calicotome spinosa (L.) Link.

3. Station "Rachgoun 2". The Rachgoun 2 station is about $6.8 \mathrm{~km}$ from the Rechgoun 1, it rises to an altitude of $16 \mathrm{~m}$ and has the following Lambert coordinates: $1^{\circ} 43^{\prime}$ West longitude, $35^{\circ} 26^{\prime}$ North latitude.

The rate of vegetation cover varies from 60 to $70 \%$ on a slope of $30 \%$ to $40 \%$ with a vegetation dominated by chamaephytes: Chamaerops humilis, Lavandula dentata L., Drimia maritima and some annuals: Hordeum murinum L., Bellis sylvestris L., and Avena sterilis L.

\section{Methodology in the field}

As done previously (Meftah et al., 2019), we followed a methodology comprising two stages, the first in the field and the second in the laboratory where physical and chemical analysis were carried out.

We took our samples in the different profiles in relation to the inclination of the slope. For each station, we have determined 3 fairly wide profiles along the slope, and, from each profile, we took two samples: one on the surface (surface horizon) and the other in depth (depth horizon), for a total of 6 samples taken at each station. The methods used are those outlined by Aubert (1978) in his soil manual analyzes.

\section{Methodology in the laboratory}

The soil samples were sent to the soil testing laboratory for different treatments: 
1. Physical analyzes: Granulometry, Stokes particle size method.

2. Chemical analysis.

3. $\mathrm{pH}$ : Electrometric method.

4. $\mathrm{CaCO} 3$ (Total limestone): Bernard Calcimeter Method.

5. Organic matter: Anne Method (1945). The total organic matter content of the soil is generally obtained by measuring the carbon content. The organic matter to carbon ratio is estimated to be around 1.72 (Aubert, 1978).

6. Electrical conductivity: method of diluted extract or extract a fifth $(1 / 5)$. The measurements are expressed in $\mathrm{mS} / \mathrm{cm}$.

7. Munsell coloring (1971): the color of the soil, expression of the presence of organic matter and various elements (trace elements, macro-elements) can vary from one profile to another and from one sample to another.

8. Bioclimatic aspect of the study area: our study stations are located in the upper semi-arid bioclimatic stage in warm winter and in the lower semiarid in temperate winter.
According to the thermal classification of Debrach (1959), we have two types of climate, namely, semi-continental for the station of Remchi and coastline for the station of Béni-Saf. According to Sari-Ali (2012), this difference is due to the combined influence of the sea, terrain and altitude.

\section{RESULTS}

Results of physico-chemical analysis on the soil of Remchi, Rachgoun 1, and Rachgoun 2 Stations are shown in Tables 1-3.

\section{DISCUSSION AND CONCLUSIONS}

The results obtained with these new samples confirm what already observed previously (Meftar et al., 2019). The low clay content also found in these new samplings (Remchi: Profile 1: Horizon 1 clays $9 \%$, Profile 2 : Horizon 1: Clays $12 \%$, Profile

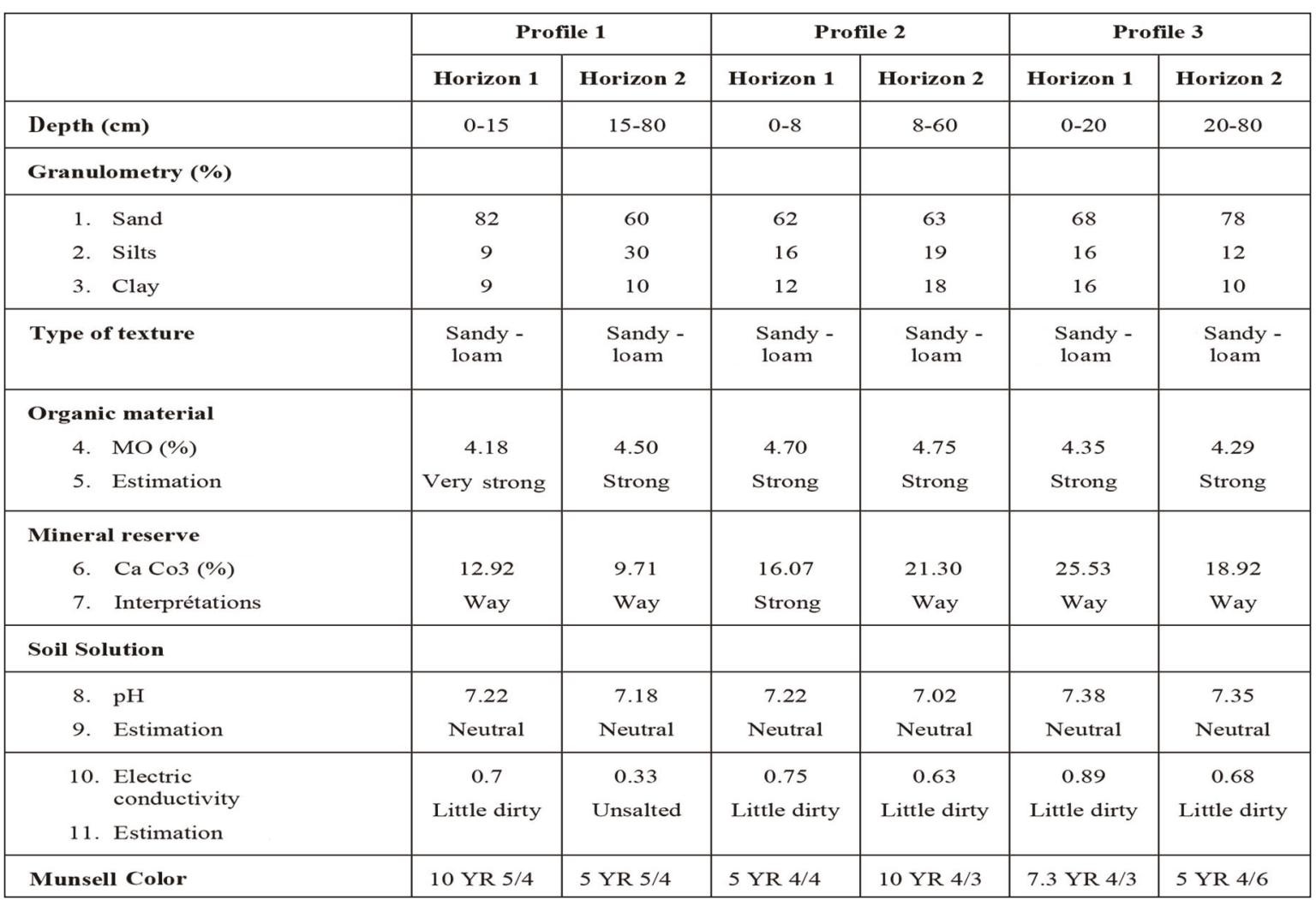

Table 1. Results of physico-chemical analysis of Remchi soil. 


\begin{tabular}{|c|c|c|c|c|c|c|}
\hline & \multicolumn{2}{|c|}{ Profile 1} & \multicolumn{2}{|c|}{ Profile 2} & \multicolumn{2}{|c|}{ Profile 3} \\
\hline & Horizon 1 & Horizon 2 & Horizon 1 & Horizon 2 & Horizon 1 & Horizon 2 \\
\hline \multicolumn{7}{|l|}{ Granulometry (\%) } \\
\hline 2. Silts & 16 & 10 & 10 & 15 & 5 & 17 \\
\hline 3. Clay & 5 & 5 & 2 & 3 & 5 & 6 \\
\hline Type of texture & Sandblaster & Sandblaster & Sandblaster & Sandblaster & Sandblaster & Sandblaster \\
\hline \multicolumn{7}{|l|}{ Organic material } \\
\hline \multicolumn{7}{|l|}{ Mineral reserve } \\
\hline 6. $\mathrm{CaCo} 3(\%)$ & 22.05 & 17.94 & 10.76 & 20.00 & 14.35 & 18.46 \\
\hline 7. Interprétations & Average & Average & Average & Average & Average & Average \\
\hline \multicolumn{7}{|l|}{ Soil Solution } \\
\hline 8. $\mathrm{pH}$ & 7.07 & 7.15 & 7.05 & 7.08 & 7.06 & 7.04 \\
\hline 9. Estimation & Neutral & Neutral & Neutral & Neutral & Neutral & Neutral \\
\hline \multicolumn{7}{|l|}{ Electric conductivity } \\
\hline 10. Valor & 0.58 & 0.65 & 0.49 & 0.43 & 0.52 & 0.47 \\
\hline 11. Estimation & Unsalted & Unsalted & Unsalted & Unsalted & Unsalted & Unsalted \\
\hline
\end{tabular}

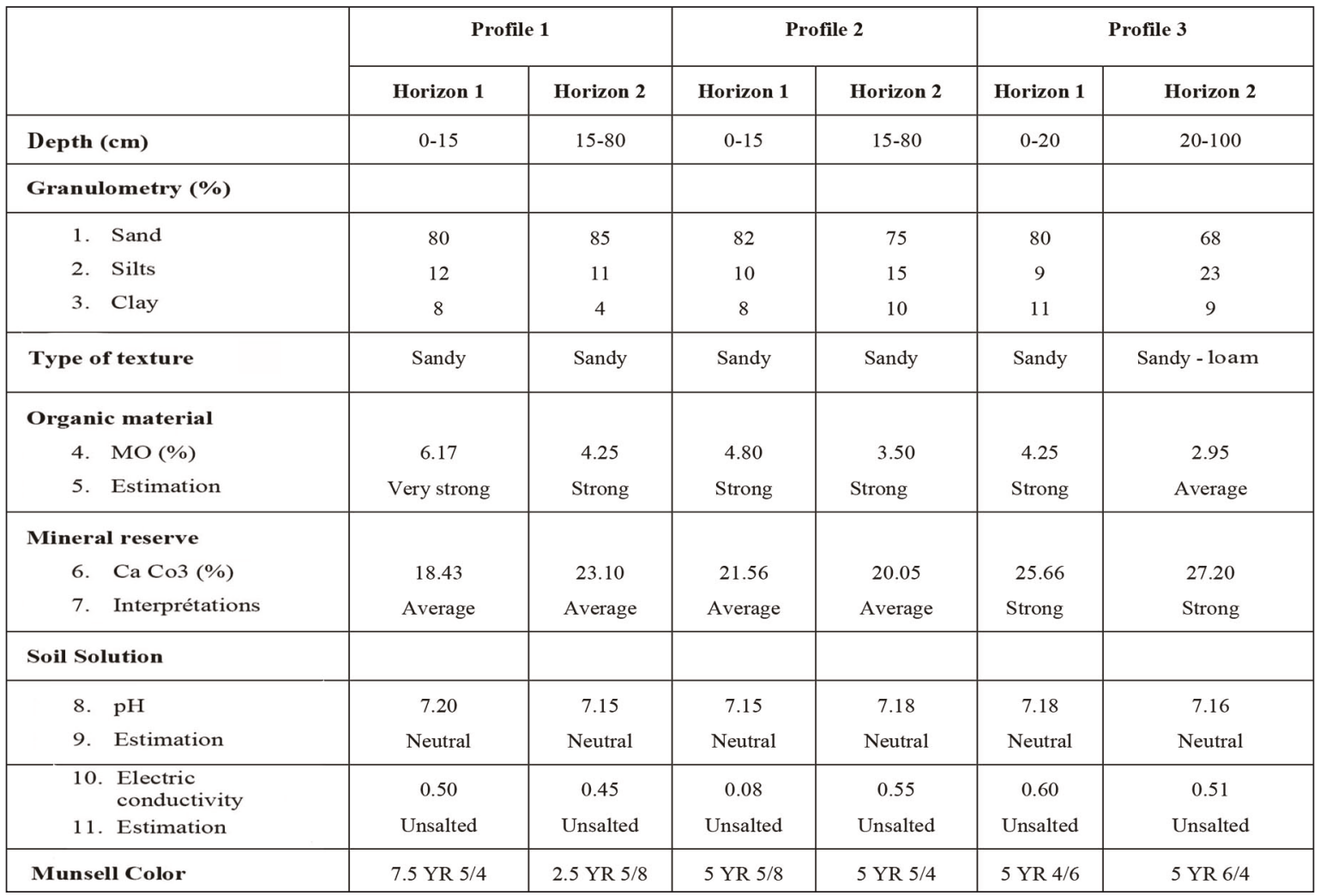

Table 2 (above). Results of physico-chemical analyzes of Rechgoun soil 1.

Table 3 (bottom). Results of physico-chemical analyzes of Rechgoun soil 2. 
3: Horizon 1: Clays 16\%, Rechgoun Profile 1: Horizon 1: Clays 3, Profile 3: Horizon 1: $5 \%$ clays and Horizon 2: 6\% clays) leads to poor structural stability of the soil and therefore to degradation of the surface through erosion visible on these slopes with also a decrease in the percentages of sands towards depth horizons (Tables 1-3).

Soils affected by these phenomena are often richer than other components (Remchi: Profile 2: Horizon 1: silt 16\% and Horizon 2: silt 19\%, Profile 3: Horizon 1: silt 16\%, in silt and/or fine sand (Profile 1: Horizon 1 sands $82 \%$ and Horizon 2: sands: $60 \%$, Profile 2: Horizon 1: sands $62 \%$ and Horizon 2: sands $63 \%$, Profile 3 : Horizon 1: sands $68 \%$ and Horizon 2: sands 78\%). The silts are very fine particles and have a weak cohesion. They are therefore easily detached from the soil matrix and easily transported by runoffs. Fine sands have an even weaker cohesion and coarse sands have a very weak cohesion.

An approximate range for an ideal clay content would be between $15 \%$ and $30-40 \%$. Below 15\%, the structural stability becomes relatively low and the soil easily eroded. Beyond about $40 \%$, the soil show with high water retention and a massive structure (Merzouk et al., 2009; Mezouar, 2016).

It is necessary to study this phenomenon even better, even with further environmental, vegetational and mineralometric investigations, but it is evident that the most vulnerable soils should not be damaged by human activity but affected by recovery and protection projects.

\section{REFERENCES}

Anne P., 1945. Sur le dosage rapide du carbone organique des sols. Annales Agronomiques, 15: 161172.

Aubert G., 1978. Méthodes d'analyses du sol. 2ème Edition C.N.D.P. Marseille, 199 pp.

Aubert Guy \& Chalabi N., 1981. Contribution l'étude édaphique des groupements Quercus cerris su. P. Pseudocerris cedruslibani et Abies cilica dans le NordOuest de la Syrie. Ecologia Mediterranea: 23-35.

Baize D., 1988. Guide des analyses courantes en pédologie. INRA, Paris, 172 pp.

Benabadji N., Bouazza M., Metge M. \& Loisel R., 1996. Description et aspects des sols en région semi aride et aride au Sud de Sebdou (Oranie, Algérie). Bulletin Institut Sciences (Rabat), 20: 77-86.

Benabdelmoumene F., 2018. Contribution à une étude phytoécologique des peuplements situés dans la région de Hammam Boughrara (Oranie). Université Abou Bakr Belkaid Faculté SNV-STU Département d'Ecologie et Environnement, Thèse de doctorat en écologie végétale, $190 \mathrm{pp}$.

Collier D., Gachon L. \& Robelin M., 1957. Cinquieme année d'expérience en cases d'essai de végétation de la station d'agronomie du massif centrale. Essai sur l'orge de printemps. Comptes rendus de l'Académie des Sciences du 26 juin.

Debrach J., 1959. Notes sur le climat du Maroc Occidental. Maroc Médical, 32: 1122-1134.

Duchauffour Ph., 1977. Pédologie, Pédogénèse et classification, Tome I. Ed. Masson, Paris, 477 pp.

Guinochet M., 1973. Phytosociologie. Ed. Masson, Paris, $227 \mathrm{pp}$.

Lahouel N., Benabadji N. \& Benmansour D., 2014. Characterization of the organic matter in the formations with Juniperus phoenicea, and Pinus halepensis in the matorral of the Mostaganémois littoral. Chemistry, Open Journal of Ecology, 4: 253-261.

https://doi.org/10.4236/OJE.2014.45024

Laperche V. \& Moussman J.R., 2004. Protocol of Sampling of the Uurbain. Ground Polluted by Lead, RP52928-FR, Thèse Doc Pdf.

Meftah F.Z., Benabadji N. \& Merzouk A., 2019. Physico-Chemical Complex of Matorral Soils of the North Western Region of Algeria. Open Journal of Ecology, 9: 134-144.

https://doi.org/10.4236/oje.2019.95011

Merzouk A., Benabadji N., Benmansour D. \& Thinon M., 2009. Quelques aspect édapho-floristique des peuplements halophiles de l'Algérie occidentale. Première partie: aspect édaphiques. Bulletin de la societe linneenne de Provence, 60: 1-15.

Meziane H., 2010. Contribution à l'étude des Groupements Psammophytes de la région de Tlemcen (Algérie occidentale). Thèse Doctorat Université Tlemcen, $230 \mathrm{pp}$.

Mezouar K., 2016. Soil-vegetation. Relation in south of Tlemcen region. Mémoire de Magister, Université de Tlemcen, pp. 51-72.

Munsell Soil Color Charts, 1971. Munsell color company Inc, Baltinore, Mary land 21218 USA.

Ozenda P., 1977. Flore du Sahara. 2ème éd. revue et complétée. Editions du Centre national de la recherche scientifique, Paris, 622 pp.

Robert M., 1992. Le sol, ressource naturelle à préserver pour la protection de l'environnement. Cahiers Agricultures, 1: 20-34.

Roose E., 1991. Conservation des sols en zones méditerranéennes Synthèse et proposition d'une nouvelle stratégie de lutte antiérosive: la GCES. Cahiers O.R.S.T.O.M. (Office de la recherche scientifique et technique outre-mer), Serie Pedologie, 26: 145-181. 
Ruellan A., 1972. Contribution à la connaissance des sols méditerranéens: les sols à profil calcaire différencié des plaines de la Basse Moulouya (Maroc oriental). Revue géographique des Pyrénées et du Sud-Ouest. Sud-Ouest Européen, 43: 285-287
Sari-Ali A., 2012. Contribution à l'étude des peuplements à Arthrocnemum glaucum (Del.) Ung. de l'Oranie (Algérie occidentale) taxonomie et bio-écologie. Thèse Doctorat Université Tlemcen, Algeria, 245 pp. 